\title{
Effect of the combination of a cyclooxygenase-1 selective inhibitor and taxol on proliferation, apoptosis and angiogenesis of ovarian cancer in vivo
}

\author{
WEI LI，MEI-LIN LIU，JIA-HUI CAI，YUN-XIAN TANG，LING-YUN ZHAI and JUN ZHANG
}

Department of Gynecology, Nanjing Medical University of Hangzhou Hospital, Hangzhou, Zhejiang 310006, P.R. China

Received January 19, 2012; Accepted April 13, 2012

DOI: $10.3892 / \mathrm{ol} .2012 .688$

\begin{abstract}
This study was designed to investigate the effects of a cyclooxygenase (COX)-1 inhibitor, SC-560, administered in combination with taxol, on the molecular mechanisms of antitumor efficacy in a SKOV-3 human ovarian carcinoma cell xenograft-bearing mouse model. The mice were treated with $6 \mathrm{mg} / \mathrm{kg} /$ day SC-560 by gavage twice every other day and $20 \mathrm{mg} / \mathrm{kg}$ taxol by intraperitoneal injection once a week for three weeks. Microvessel density (MVD) and vascular endothelial growth factor (VEGF) mRNA levels of ovarian cancer were detected in the tumor tissues using immunohistochemistry and reverse transcription-polymerase chain reaction (RT-PCR), respectively. The index of proliferating and apoptotic cells in the tumor tissues was determined by staining for Ki-67 and using the terminal deoxynucleotidyl transferase-mediated dUTP nick end labeling (TUNEL) method, respectively. On day 7 after the end of administration, the tumor volume of mice in the combination group was reduced by $55.35 \%$ compared with that of the control mice, and the difference was statistically significant $(\mathrm{P}<0.05)$. In the combination group, the expression of VEGF, MVD and the cell proliferation index were inhibited significantly, while the apoptotic index was notably increased (all $\mathrm{P}<0.01$, compared with the control group). Our results indicate that the molecular mechanisms of the antitumor efficacy of SC-560 combined with taxol therapy may act in part by inhibiting tumor angiogenesis, reducing cell proliferation and inducing cell apoptosis.
\end{abstract}

\section{Introduction}

Ovarian cancer is the fifth most common cause of cancerrelated mortality among women (1). Over the past two decades, despite recent advances in surgery and chemotherapy,

Correspondence to: Dr Wei Li, Department of Gynecology, Nanjing Medical University of Hangzhou Hospital, 261 Huansha Road, Hangzhou, Zhejiang 310006, P.R. China

E-mail: wei5901482@tom.com

Key words: ovarian cancer, SC-560, taxol, microvessel density, vascular endothelial growth factor, Ki-67, apoptosis the overall cure rate of ovarian cancer has remained approximately 30\% (2). Taxol has been widely used in the treatment of cancers, including ovarian cancer $(3,4)$. However, the multidrug resistance of tumor cells has been the main cause for the failure of chemotherapy. Combination chemotherapy is one of the strategies being used to overcome drug resistance. The current standard of initial chemotherapy for ovarian cancer is carboplatin and paclitaxel (5).

Previous studies have reported the inhibitory effects of COX-2 inhibitors in combination with taxol on tumor growth $(6,7)$. The results demonstrated clear antagonistic effects when COX-2 inhibitors were administered concurrently with taxol. Cyclooxygenase (COX) is a key enzyme that catalyzes the committed step in prostaglandin synthesis (8). Two enzyme isoforms of COX are known, referred to as COX-1 and COX-2 (9). COX-1 is constitutively expressed in most tissues and plays a role in various physiological functions, whereas COX-2 is transiently inducible by stimuli such as cytokines, growth factors, mitogens, tumor promoters and hormones, and also regulates inflammation, differentiation, mitogenesis and angiogenesis $(8,9)$. Previous findings showed that COX-1 is the predominant $\mathrm{COX}$ isoform expressed in ovarian cancer (10-14). These results suggest that COX-1 is a target for the prevention and/or treatment of epithelial ovarian cancer. In addition, numerous studies have shown that COX-1 selective inhibitors may have potent antitumor activity in combating ovarian tumors $(10,12,13,15)$. These results indicate that COX-1 is involved in the progression of ovarian carcinoma and that COX-1 selective inhibitors may inhibit tumor growth by inhibiting tumor angiogenesis, reducing cell proliferation and/ or accelerating apoptosis. However, studies of the combined effects and antitumor mechanisms of COX-1 inhibitors and taxol on ovarian cancer have not yet been reported.

In this study, we investigated the effects of SC-560, a COX-1 inhibitor, combined with taxol, on the growth of tumors, cell proliferation, apoptosis and angiogenesis using nude mice transplanted with a human ovarian cancer SKOV-3 cell line as an experimental model system.

\section{Materials and methods}

Human ovarian tumors in nude mice. In the present study, we used SKOV-3 cells to study tumor growth in vivo. The 
SKOV-3 cells were implanted subcutaneously into the dorsal skin $\left(2 \times 10^{6}\right.$ cells $)$ of female athymic nude mice $(\mathrm{nu} / \mathrm{nu}$, 7-8 weeks old). When the tumors were visible (7 days after inoculation), the mice were randomly divided into four groups, ( $n=6$ mice per group): the SC-560 group, the taxol group, the combination group (SC-560 plus taxol), and the control group. SC-560 (Sigma Chemical Co., St. Louis, MO, USA) was administered by oral gavage twice every other day at a dose of $6 \mathrm{mg} / \mathrm{kg} /$ day. Taxol (Bristol Myers Squibb SRL, Italy) was administered by intraperitoneal injection once a week at a dose of $20 \mathrm{mg} / \mathrm{kg}$. The drugs were suspended in a $0.5 \mathrm{ml}$ solution of $0.5 \%$ methycellulose and $0.025 \%$ Tween-20 (both obtained from Sigma Chemical Co.). The dose of SC-560 was selected for its specificity in inhibiting COX isotypes (16). The control group was administered $0.9 \%$ normal saline by gavage twice every other day at a dose of $0.5 \mathrm{ml}$ a time as well as $0.9 \%$ normal saline administered intraperitoneally once a week at a dose of $0.5 \mathrm{ml}$. The drugs or vehicle were administered over a period of 21 days, commencing 7 days after the tumors became palpable.

A linear caliper was used to measure tumor dimensions twice a week, and the tumor volume was calculated using the equation $\mathrm{V}\left(\mathrm{mm}^{3}\right)=a \times b^{2} / 2$, where $a$ is the largest diameter and $b$ is the smallest diameter (17). Tumor growth was evaluated by the inhibition rate and calculated using the formula: $I R=C-T / C \times 100 \%$, where $I R$ is the mean inhibition rate, $T$ is the mean tumor volume in the treatment group, and $C$ is the mean tumor volume in the control group. The animals were weighed weekly throughout the experiment. On day 28 , the mice were sacrificed, and tumor tissue samples were collected and then fixed in $10 \%$ phosphate-buffered formalin solution for immunohistology or stored at $-80^{\circ} \mathrm{C}$ until analysis. The tumor tissue samples were snap-frozen in liquid nitrogen prior to storage at $-80^{\circ} \mathrm{C}$.

Reverse transcription-polymerase chain reaction (RT-PCR). Total RNA was isolated from tissues using TRIzol reagent from Invitrogen Life Technologies (Carlsbad, CA, USA), according to the manufacturer's instructions. Total RNA $(5 \mu \mathrm{g})$ was reverse-transcribed using SuperScript II from Invitrogen Life Technologies according to the manufacturer's instructions. Transcribed products were subjected to PCR for VEGF (sense primer, 5'-atggacgtctaccagcgaag-3'; antisense primer, 5'-aatgctttctccgctctgaa-3') and $\beta$-actin (sense primer, 5'-ttgctgacaggatgcagaag-3'; antisense primer, 5'-acatctgctgg aaggtggac-3'). The oligodeoxynucleotides were synthesized on a Model DNA synthesizer (Shenggong, Shanghai, China). Amplification for VEGF cDNA started with a 3-min denaturation cycle at $94^{\circ} \mathrm{C}$ followed by a $30-\sec$ denaturation at $94^{\circ} \mathrm{C}, 30-$ sec annealing at $52^{\circ} \mathrm{C}, 30-$ sec extension at $72^{\circ} \mathrm{C}$ and a final extension at $72^{\circ} \mathrm{C}$ for $15 \mathrm{~min}$. The PCR profile for $\beta$-actin consisted of a 3 -min initial denaturation cycle at $94^{\circ} \mathrm{C}$ followed by a 1-min denaturation at $94^{\circ} \mathrm{C}, 1-\mathrm{min}$ annealing at $55^{\circ} \mathrm{C}$ and 1 -min extension at $72^{\circ} \mathrm{C}$. The PCR mixture was then maintained at $72^{\circ} \mathrm{C}$ for $15 \mathrm{~min}$ for final extension. The composition of the PCR mixture has been described previously (18). Final PCR products were then electrophoresed on $2 \%$ agarose gel and stained with ethidium bromide. Ultraviolet (UV)-illuminated gels were captured using Polaroid Type 667 films. Photographs were quantitated using a Bio-Rad 2000 image scanner. The intensity of $\beta$-actin amplification was used as an internal standard. The results of real-time PCR were analyzed by the DCT method: $\triangle \mathrm{CT}=\mathrm{CT}$ selected gene $-\mathrm{CT}_{\beta \text {-actin }}$, RQ (relative quantitation) $=2^{-\Delta \mathrm{CT}} \times 100 \%$. The results of realtime PCR were presented as the ratio between the selected genes and $\beta$-actin transcripts.

Immunohistochemistry. Immunohistochemistry was performed as previously described (19). Sections were deparaffinized and hydrated by sequential immersion in xylene and graded alcohol solutions. Immunohistochemical staining was performed using the streptavidin-biotin method. For the staining for $\mathrm{CD}_{34}$, the sections were immersed in normal goat serum for $34 \mathrm{~min}$. Microvessel density (MVD) was evaluated according to the method first described by Weidner et al (20). The entire tumor section was first carefully scanned using low magnification light microscopy $(x 40)$ to locate the area demonstrating the most intense neovascularization. As the immunohistochemistry of $\mathrm{CD}_{34}$ revealed slight heterogeneity within the same tumor, the five most highly vascularized areas (hot spots) were selected in x200 magnification fields. The mean of five counts was calculated and used in the statistical analysis. Sections of the tumor samples were also fixed in $10 \%$ neutral-buffered formalin and processed for immunohistochemistry (H\&E staining). The proliferation index was evaluated by staining for Ki-67. Following deparaffinization, the tissue sections were heated at $121^{\circ} \mathrm{C}$ for $15 \mathrm{~min}$ in $10 \mathrm{mM}$ Tris $\mathrm{HCl}$ with $1 \mathrm{mM}$ EDTA ( $\mathrm{pH}$ 9.0). Endogenous peroxidase was blocked with $3 \%$ hydrogen peroxide in methanol for $10 \mathrm{~min}$ at room temperature. The samples were incubated with $\mathrm{Ki}-67$ antibody [clone MIB-5 (M7248)] for $90 \mathrm{~min}$ at room temperature. The sections were then incubated in EnVision reagent for $40 \mathrm{~min}$ and $\mathrm{DAB} / \mathrm{H}_{2} \mathrm{O}_{2}$ for $8-12 \mathrm{~min}$ at room temperature. Proliferation was assessed by counting the number of nuclei stained positive for Ki-67 and the total number of cancer cells at a magnification of $\mathrm{x} 400$ in five representative regions of the tumor. Results are expressed as the proportion of positively stained cells over the total number of cells. The proliferation index was calculated as: (number of Ki-67-labeled cells/total number of cells) $\mathrm{x} 100 \%$.

TUNEL assay. Terminal deoxynucleotidyl transferasemediated dUTP nick end labeling (TUNEL) assay was used to measure apoptosis using a TUNEL kit from Chemicon Co. Beijing Zhongshan Biotechnology Co., China). TUNEL assay is a method of demonstrating apoptotic cell death. The tissue samples were fixed in $4 \%$ paraformaldehyde (PFA) for $24 \mathrm{~h}$ then dehydrated and embedded in paraffin. The paraffinembedded tissues were cut into $4-\mu \mathrm{m}$ sections. Following deparaffinization in a graded alcohol series, the tissue sections were covered with $20 \mu \mathrm{g} / \mathrm{ml}$ proteinase $\mathrm{K}$ in phosphatebuffered saline (PBS) for $15 \mathrm{~min}$ at room temperature, and endogenous peroxidase activity was blocked. The samples were then incubated with TdT enzyme and biotin-16-dUTP in TdT buffer containing $0.01 \%$ bovine serum albumin for $1.5 \mathrm{~h}$ at $37^{\circ} \mathrm{C}$ in a humidity chamber. The avidin-biotin complex (ABC) method was used to detect biotin-16-dUTP nucleotides that had been incorporated into DNA fragments using DAB as the chromogen. In each tissue specimen, five high-power fields at X400 magnification were randomly selected and the apoptotic index (AI) was calculated as the percentage of positive 
Table I. The $\triangle \mathrm{CT}$ of VEGF in the four groups (control, SC-560, taxol and SC-560/taxol combination group). ${ }^{\mathrm{a}}$

\begin{tabular}{llllr}
\hline VEGF & Control & SC-560 & Taxol & SC-560 + taxol \\
\hline 121 & $6.94 \pm 0.23$ & $7.13 \pm 0.30$ & $7.87 \pm 0.32$ & $9.14 \pm 0.33$ \\
165 & $4.58 \pm 0.26$ & $5.34 \pm 0.30$ & $6.28 \pm 0.49$ & $7.00 \pm 0.48$ \\
189 & $6.34 \pm 0.23$ & $6.54 \pm 0.21$ & $7.79 \pm 0.29$ & $8.99 \pm 0.23$ \\
\hline
\end{tabular}

${ }^{\mathrm{a}}$ Molecular isoforms of VEGF were generated by alternative splicing, rendering proteins containing 189-, 165- and 121-amino acid residues. VEGF 189, 165 and 121 were routinely detected in this series of ovarian cancer.

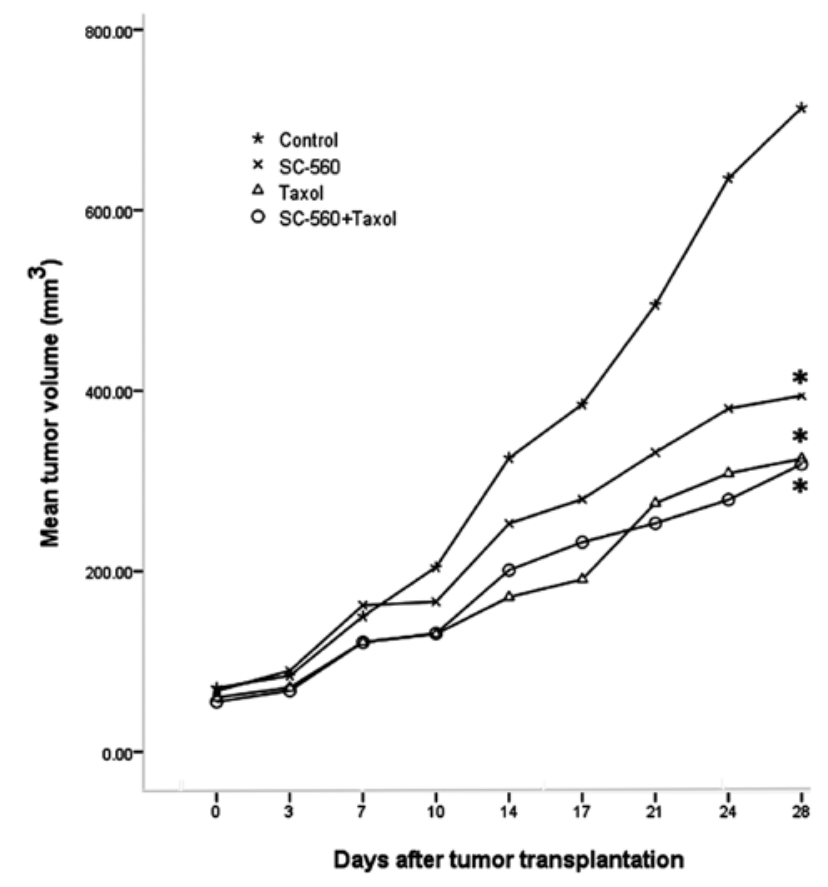

Figure 1. Effects of SC-560 and taxol on tumor growth in vivo. The inhibitory effect of SC-560 and taxol on tumor growth was determined in an ovarian cancer model using SKOV-3 cells. After 7 days had elapsed to allow for tumor establishment, mice were treated with SC-560 and taxol for 21 days. Average tumor volume of mice in all treatment groups was significantly different from vehicle-treated mice on day $28 .{ }^{*} \mathrm{P}<0.05$, compared with control.

cells, using the equation: $\mathrm{AI}=$ (number of positive cells/total number of cells) $\times 100 \%$ (21).

Statistical analysis. Statistical analysis was performed using SPSS software (SPSS version 17.0, SPSS). Statistical significance between the control and treated groups was determined using the Student's t-test. The experimental data were shown as the means \pm standard error $(\mathrm{SE}) . \mathrm{P}<0.05$ was considered to indicate a statistically significant result.

\section{Results}

Inhibition of ovarian cancer growth. Tumor growth increased throughout the study period in the control group, whereas growth was gradually suppressed in the treatment groups. Fig. 1 shows the relative effect of SC-560 and/or taxol therapy. On day 28, the tumor volume of mice in the SC-560, taxol and

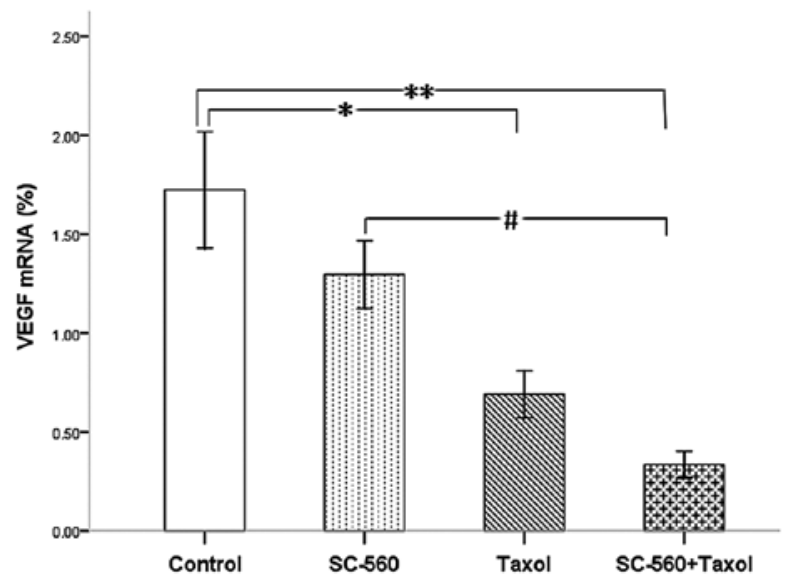

Figure 2. Effects of the drugs on the expression of VEGF mRNA. "P<0.05; ${ }^{* *} \mathrm{P}<0.01 ;{ }^{\#} \mathrm{P}<0.05$; bars indicate standard error.

combination groups was reduced by $44.67,54.48$ and $55.35 \%$, respectively, compared with the control mice. The inhibitory effect observed in the SC-560, taxol and combination groups was statistically significant compared with that of the control group $(\mathrm{P}<0.05$ for all).

Effect on VEGF production. In this study, we measured VEGF levels in xenograft tumors by real-time PCR analysis. Four molecular isoforms of VEGF were generated by alternative splicing, rendering proteins containing 206-, 189-, 165- and 121-amino acid residues (22). Although VEGF 206 transcripts were not amplified, VEGF 189, 165 and 121 were routinely detected in this series of ovarian cancer. Real-time PCR analysis indicated the $\triangle \mathrm{CT}$ (cycle threshold, $=\mathrm{CT}$ selected gene $-\mathrm{CT}_{\beta \text {-actin }}$ ) of VEGF in the four groups (Table I). A comparison of the results of the control and treatment groups revealed the expression levels of VEGF mRNA to be significantly suppressed in the taxol $(\mathrm{P}<0.05)$ and combination groups $(\mathrm{P}<0.01)$ (Fig. 2$)$. The combination therapy demonstrated a more synergistic effect than SC-560 on the inhibition of mRNA expression $(\mathrm{P}<0.05)$.

Effect on tumor blood vessels. To evaluate the consequence of antiangiogenic therapy, we examined the residual tumors histologically. Immunohistochemical analysis of frozen tumor sections revealed a decrease in the number of $\mathrm{CD}_{34}$-positive microvessels in mice treated with SC-560 and/or taxol. The 


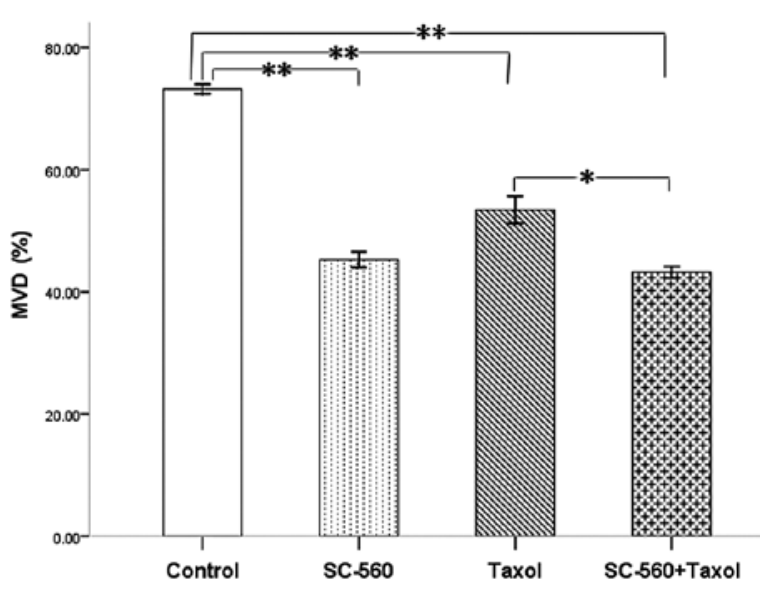

Figure 3. Effects of SC-560 and/or taxol on microvessel density (MVD) in vivo. The MVD of vehicle- and all drug-treated tumors illustrated the profound inhibitory effect of SC-560 and/or taxol. ${ }^{*} \mathrm{P}<0.05$; ${ }^{* *} \mathrm{P}<0.01$; bars indicate standard error.
MVD in the treatment groups was $45.27 \pm 1.29 \%$ (SC-560), $53.43 \pm 2.22 \%$ (taxol) and $43.20 \pm 0.94 \%$ (SC-560/taxol), which was statistically significant compared with that of the control group $(73.20 \pm 0.80 \%)(\mathrm{P}<0.01$ for all; Fig. 3$)$. In addition, the SC-560/taxol combination therapy demonstrated a greater reduction effect than taxol alone on MVD $(\mathrm{P}<0.05)$.

Effect on cell proliferation. We assessed cell growth in xenograft tumors in nude mice treated with vehicle, SC-560, taxol and SC-560/taxol using proliferation-associated nuclear antigen (Ki-67) staining. The quantification of the Ki-67positive cells in the tumors revealed that SC-560 combined with taxol treatment in nude mice resulted in a marked decrease in the proliferation index compared with the control group (Fig. 4A). Data on the proliferation index in the four groups are shown in Fig. 4B. In the SC-560 group, the proliferation index was $12.00 \pm 2.13 \%$, which is statistically significant compared with that of the control group $(24.67 \pm 4.61 \%, \mathrm{P}<0.05)$. The

A
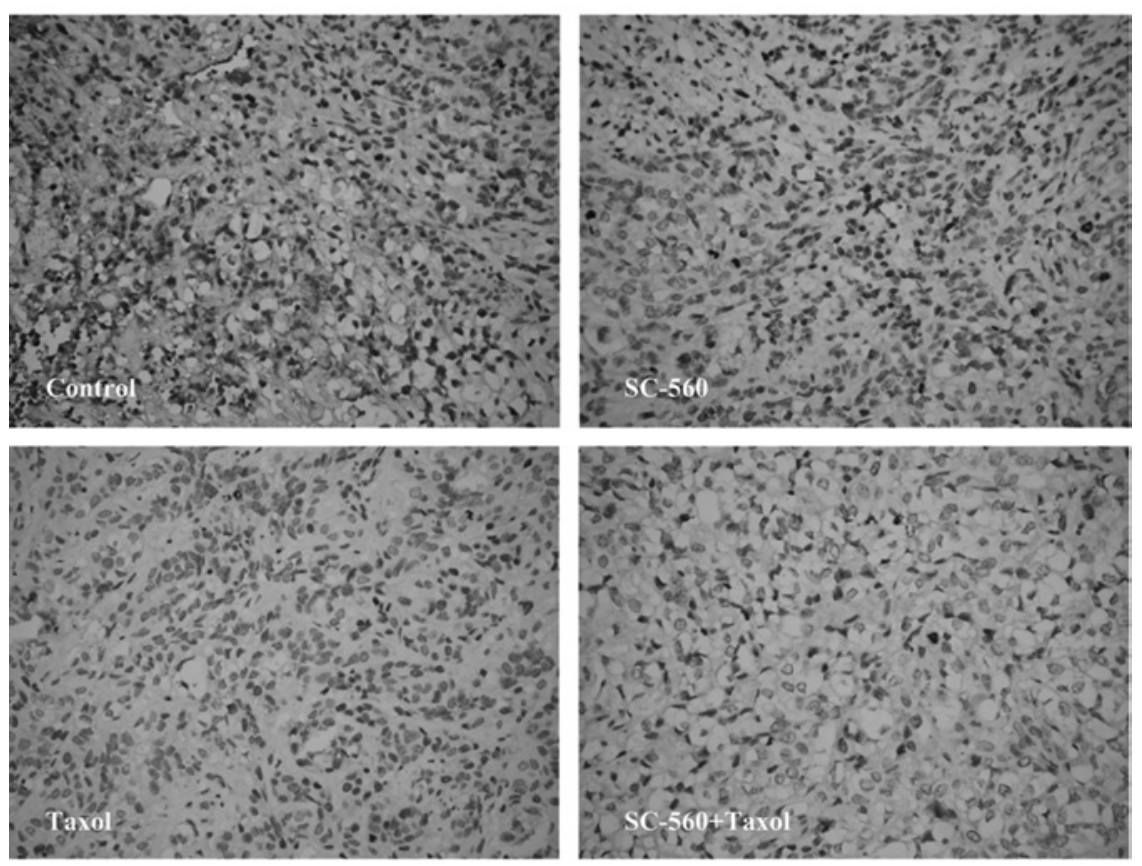

B

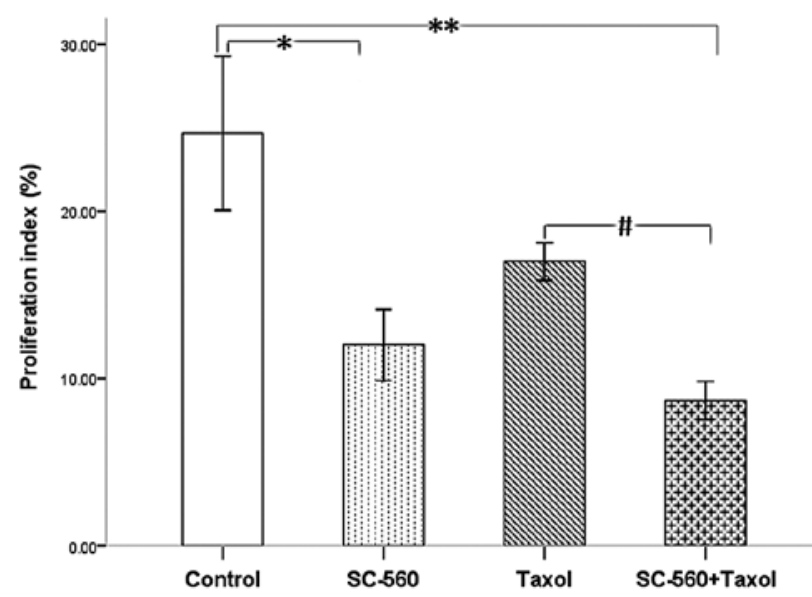

Figure 4. Cell proliferation in xenograft tumors of nude mice treated or not treated with SC-560 and/or taxol. (A) Representative photomicrograph of Ki-67 staining of tumor tissue. Magnification, x400. (B) Quantitative data for the proliferation index is shown as a percentage of Ki-67-positive cells. The proliferation index shows the proliferation inhibition of SC-560 and/or taxol on tumors. ${ }^{*} \mathrm{P}<0.05 ;{ }^{* *} \mathrm{P}<0.01 ;{ }^{*} \mathrm{P}<0.05$; bars indicate standard error. 
$\mathbf{A}$
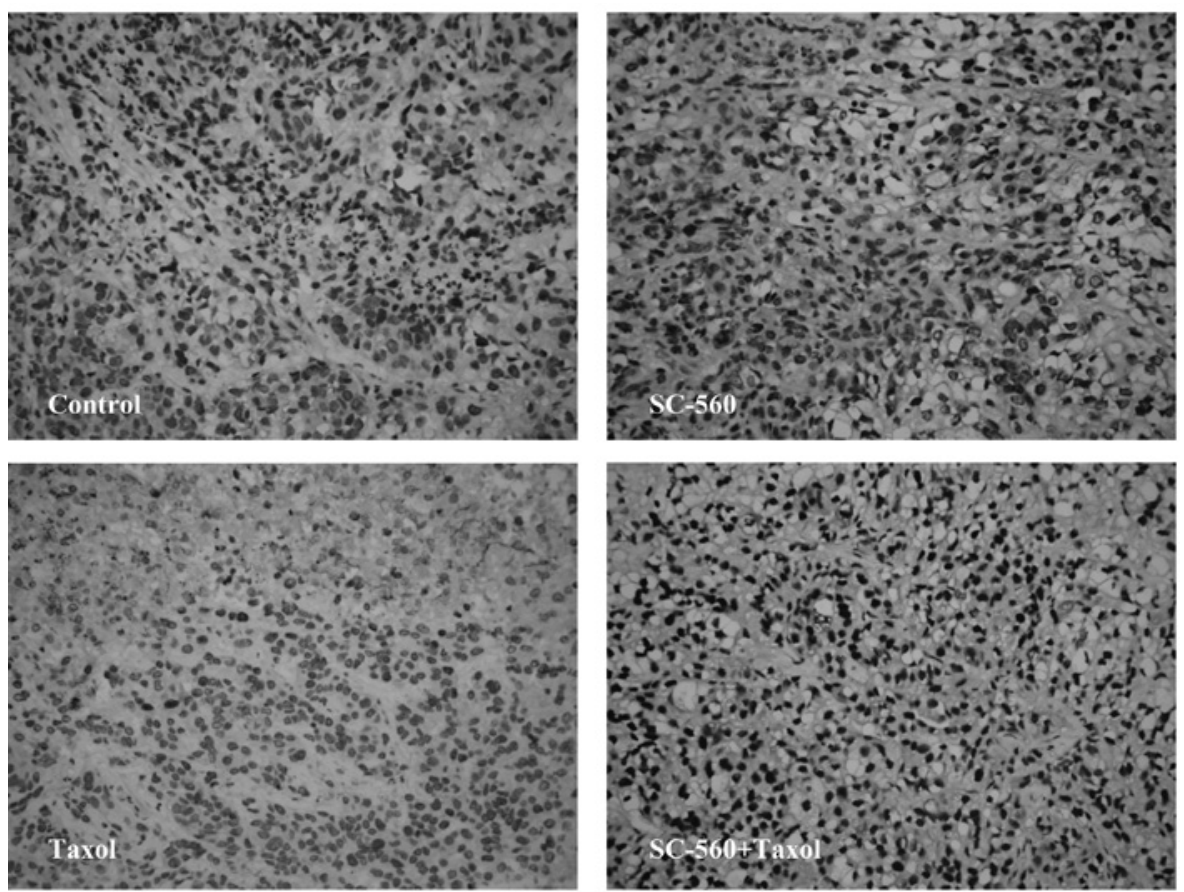

B

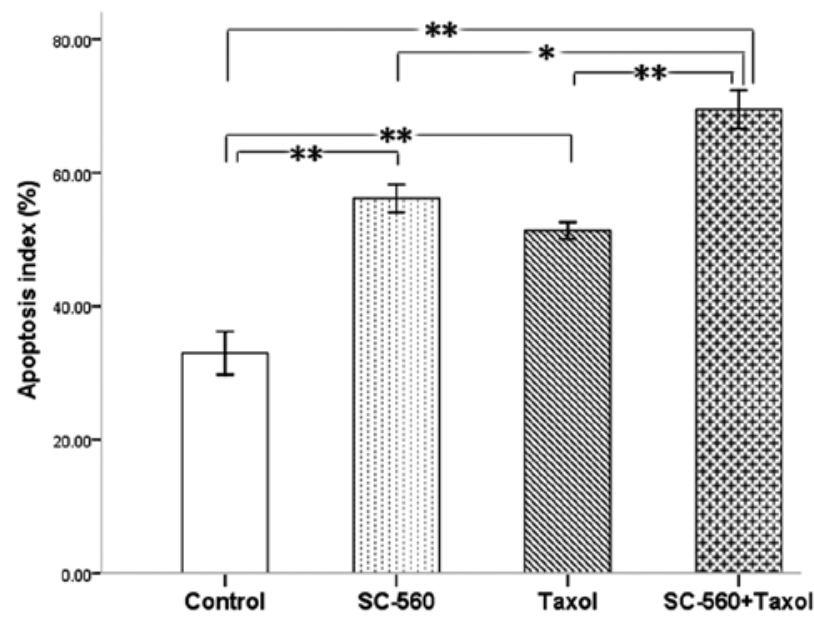

Figure 5. Cell apoptosis in xenograft tumors of nude mice treated or not treated with SC-560 and/or taxol. (A) Apoptotic cells of tumor tissue. Magnification, $\mathrm{x} 400$. (B) Quantitative data for the apoptotic index is shown as a percentage of TUNEL-positive cells. The apoptotic index illustrates the apoptotic induction of SC-560 and/or taxol on tumors. ${ }^{*} \mathrm{P}<0.05 ;{ }^{* *} \mathrm{P}<0.01$; bars indicate standard error.

combination group demonstrated a notable reduction in the proliferation index $(8.67 \pm 1.15 \%)$ compared with the control group $(\mathrm{P}<0.01)$. In addition, the combination group demonstrated a greater reduction in the proliferation index compared with the taxol group $(\mathrm{P}<0.05)$.

Effect on cell apoptosis. To evaluate the extent of apoptosis in tumor tissue in the cancer-bearing mouse model, apoptotic cells were stained using the TUNEL method and the number of apoptotic-positive cells was counted in a high-power field. A notable increase in apoptotic-positive cells was observed in the combined therapy group compared with the control group (Fig. 5A). Data on the apoptotic index of the four groups are shown in Fig. 5B. The apoptotic index was 56.17 \pm 2.09 , $51.33 \pm 1.26$ and $69.50 \pm 2.87 \%$ in the SC-560, taxol and combination groups, respectively, which is statistically significant compared with that of the control group $(33.00 \pm 3.22 \%$; $\mathrm{P}<0.01$ for all). In addition, the combination group demonstrated a synergistic effect on the induction of cell apoptosis in tumors compared with the SC-560 $(\mathrm{P}<0.05)$ and taxol group $(\mathrm{P}<0.01)$.

\section{Discussion}

Numerous studies have demonstrated that COX molecules are involved in the onset and progression of a variety of malignancies and are overexpressed in ovarian cancer $(13,23,24)$. Other studies have found that COX-1, but not COX-2, is the predominant $\mathrm{COX}$ isoform expressed in human ovarian cancer $(11,12,15,25)$. Additional evidence that an elevated COX-1 expression contributes to cancer development has emerged through studies of ovarian cancer using animal models $(13,26)$. Thus, COX-1 is overexpressed in ovarian cancer, suggesting 
that COX-1 production plays a role in ovarian cancer development. The present study has shown that COX-1 selective inhibitors inhibited the growth of tumor cells by inhibiting COX-1 activity, thereby reducing prostaglandin $\mathrm{I}_{2}\left(\mathrm{PGI}_{2}\right)$ and $\mathrm{PGE}_{2}$ levels, inhibiting the production of angiogenic factors and ultimately impeding tumor angiogenesis $(10,12,27)$.

Angiogenesis refers to the recruitment of new blood vessels and forms an essential component of the metastatic pathway. Numerous studies have indicated that angiogenesis is considered essential for tumor growth and the development of metastases (28-30). As one of the most important angiogenic factors, VEGF stimulates the proliferation of endothelial cells and also increases vascular permeability and protein extravasations, which then provides nutrition and gas exchange for the growth of tumor cells (31). VEGF has been shown to play a key role in the growth and progression of ovarian cancer (32,33). Our results have shown that SC-560 and taxol therapy inhibited VEGF mRNA expression, and a combination therapy of the two drugs demonstrated a synergistic effect. Previous studies have found that the expression of COX-1 leads to an increased expression of VEGF and that the inhibition of COX-1 reverses this response $(15,34,35)$. The above studies indicate that COX-1 inhibitors may indirectly inhibit VEGF expression by inhibiting COX-1 expression. Combined with previous research results, the present study indicates that the decrease in tumor-associated VEGF by SC-560 and taxol may be a crucial mechanism in controlling angiogenesis and inducing the inhibition of overall tumor growth. Studies showed that VEGF-positive tissue was associated with a high MVD expression, whereas VEGF-negative tissue demonstrated a low expression of MVD, indicating a positive correlation between VEGF and MVD (36,37). The increase of MVD, an indirect marker of intense tumor vascularization, increases blood volume (38), and increased MVD is known to be associated with both evolution of disease and survival (39-41). Our results indicated that SC-560 and/or taxol therapy caused a marked reduction in MVD compared with vehicle-treated control, and the combination therapy revealed a synergistic effect on the inhibition of MVD. These results suggest that the potent antiangiogenic activity of SC-560 combined with taxol is the primary mechanism of inhibition of tumor growth in the animal model of ovarian cancer.

The delicate balance between apoptosis and cell proliferation is essential in controlling the cyclical growth of the reproductive tissues and plays a significant role in the prevention of neoplastic transformation $(42,43)$. Unrestricted cell proliferation and reduced apoptosis are hallmarks of cancer cells (27). Our results demonstrated that SC-560 combined with taxol therapy had a synergistic effect on the inhibition of cell proliferation and induction of apoptosis in tumors. Our previous study indicated that SC-560 inhibited the $\mathrm{PGE}_{2}$ level by inhibiting the expression of COX-1 in SKOV-3 ovarian carcinoma xenograft-bearing mice (10). Munkarah et al (44) found that $\mathrm{PGE}_{2}$ stimulated proliferation and inhibited cell apoptosis by promoting tumor angiogenesis in epithelial ovarian cancer. The above studies suggest that $\mathrm{SC}-560$ reduces the $\mathrm{PGE}_{2}$ level by inhibiting the production of COX-1, then inhibiting cell proliferation and promoting apoptosis, and finally suppressing tumor growth. It is understood that one of mechanisms by which taxol inhibits the growth of ovarian cancer is by binding selectively and reversibly to the B subunit of tubulin, promoting tubulin polymerization and the formation of stable microtubules, causing cell cycle arrest at the G2/M phase and eventually resulting in the inhibition of cell proliferation by blocking cell division and cell death through an apoptotic pathway (45). Therefore, our results suggest that taxol supplemented by COX-1 inhibitors in the treatment of ovarian cancer enhances the effect of taxol alone on the inhibition of cell proliferation and induction of apoptosis, in addition to inducing a synergistic inhibition effect on the growth of ovarian cancer.

In conclusion, this study demonstrated that the molecular mechanisms of the antitumor efficacy of SC-560 combined with taxol therapy may act in part through the inhibition of tumor angiogenesis, the reduction of cell proliferation and the induction of cell apoptosis. However, whether COX-1 inhibitors combined with taxol therapy can be adopted as a new chemotherapy regimen in the treatment of ovarian cancer requires further investigation.

\section{References}

1. Siegel R, Ward E, Brawley O and Jemal A: Cancer statistics, 2011: the impact of eliminating socioeconomic and racial disparities on premature cancer deaths. CA Cancer J Clin 61: 212-236, 2011.

2. Bast RC Jr, Hennessy B and Mills GB: The biology of ovarian cancer: new opportunities for translation. Nat Rev Cancer 9: 415-428, 2009.

3. Jain A, Dubashi B, Reddy KS and Jain P: Weekly paclitaxel in ovarian cancer - the latest success story. Curr Oncol 18: 16-17, 2011.

4. Kumar S, Mahdi H, Bryant C, Shah JP, Garg G and Munkarah A: Clinical trials and progress with paclitaxel in ovarian cancer. Int J Womens Health 2: 411-427, 2010.

5. Jelovac D and Armstrong DK: Recent progress in the diagnosis and treatment of ovarian cancer. CA Cancer J Clin 61: 183-203, 2011.

6. Bijman MN, Hermelink CA, van Berkel MP, Laan AC, Janmaat ML, Peters GJ and Boven E: Interaction between celecoxib and docetaxel or cisplatin in human cell lines of ovarian cancer and colon cancer is independent of COX-2 expression levels. Biochem Pharmacol 75: 427-437, 2008.

7. Munkarah AR, Ali-Fehmi R, Jiang JZ, Elhammady E, Malone JM Jr and Saed GM: The effects of combining docetaxel and cyclooxygenase-2 inhibitors on proliferation and apoptosis in epithelial ovarian cancer. Anticancer Drugs 18: 889-896, 2007.

8. Vane JR, Bakhle YS and Botting RM: Cyclooxygenases 1 and 2. Annu Rev Pharmacol Toxicol 38: 97-120, 1998.

9. Smith WL, Garavito RM and DeWitt DL: Prostaglandin endoperoxide $\mathrm{H}$ synthases (cyclooxygenases) -1 and -2 . J Biol Chem 271: 33157-33160, 1996

10. Li W, Ji ZL, Zhuo GC, Xu RJ, Wang J and Jiang HR: Effects of a selective cyclooxygenase-1 inhibitor in SKOV-3 ovarian carcinoma xenograft-bearing mice. Med Oncol 27: 98-104, 2010.

11. Dore M, Cote LC, Mitchell A and Sirois J: Expression of prostaglandin G/H synthase type 1, but not type 2 , in human ovarian adenocarcinomas. J Histochem Cytochem 46: 77-84, 1998.

12. Daikoku T, Wang D, Tranguch S, Morrow JD, Orsulic S, DuBois RN and Dey SK: Cyclooxygenase-1 is a potential target for prevention and treatment of ovarian epithelial cancer. Cancer Res 65: 3735-3744, 2005.

13. Daikoku T, Tranguch S, Trofimova IN, Dinulescu DM, Jacks T, Nikitin AY, Connolly DC and Dey SK: Cyclooxygenase-1 is overexpressed in multiple genetically engineered mouse models of epithelial ovarian cancer. Cancer Res 66: 2527-2531, 2006.

14. Daikoku T, Tranguch S, Chakrabarty A, Wang D, Khabele D, Orsulic S, Morrow JD, Dubois RN and Dey SK: Extracellular signal-regulated kinase is a target of cyclooxygenase-1-peroxisome proliferator-activated receptor-delta signaling in epithelial ovarian cancer. Cancer Res 67: 5285-5292, 2007.

15. Gupta RA, Tejada LV, Tong BJ, Das SK, Morrow JD, Dey SK and DuBois RN: Cyclooxygenase-1 is overexpressed and promotes angiogenic growth factor production in ovarian cancer. Cancer Res 63: 906-911, 2003. 
16. Reese J, Zhao X, Ma WG, Brown N, Maziasz TJ and Dey SK: Comparative analysis of pharmacologic and/or genetic disruption of cyclooxygenase- 1 and cyclooxygenase- 2 function in female reproduction in mice. Endocrinology 142: 3198-3206, 2001

17. Williams CS, Watson AJM, Sheng H, Helou R, Shao J and DuBois RN: Celecoxib prevents tumor growth in vivo without toxicity to normal gut: lack of correlation between in vitro and in vivo models. Cancer Res 60: 6045-6051, 2000.

18. Seki A, Kodama J, Miyagi Y, Kamimura S, Yoshinouchi M and Kudo T: Amplification of the mdm-2 gene and $\mathrm{p} 53$ abnormalities in uterine sarcomas. Int J Cancer 73: 33-37, 1997.

19. Li W, Xu RJ, Jiang LH, Shi JF, Long X and Fan B: Expression of cyclooxygenase-2 and inducible nitric oxide synthase correlates with tumor angiogenesis in endometrial carcinoma. Med Oncol 22: 63-70, 2005 .

20. Weidner N, Semple JP, Welch WR and Folkman J: Tumor angiogenesis: a new significant and independent prognostic indicator in early-stage breast carcinoma. J Natl Cancer Inst 84: 1875-1887, 1992.

21. Kitamura T, Itoh M, Noda T, Matsuura M and Wakabayashi K: Combined effects of cyclooxygenase-1 and cyclooxygenase- 2 selective inhibitors on intestinal tumorigenesis in adenomatous polyposis coli gene knockout mice. Int J Cancer 109: 576-580, 2004.

22. Ferrara N, Leung DW, Cachianes G, Winer J and Henzel WL: Purification and cloning of vascular endothelial growth factor secreted by pituitary folliculostellate cells. Methods Enzymol 198: 391-405, 1991.

23. Bernard MP, Bancos S, Sime PJ and Phipps RP: Targeting cyclooxygenase- 2 in hematological malignancies: rationale and promise. Curr Pharm Des 14: 2051-2060, 2008.

24. Ali-Fehmi R, Che M, Khalifeh I, Malone JM, Morris R, Lawrence WD and Munkarah AR: The effect of cyclooxygenase-2 expression on tumor vascularity in advanced stage ovarian serous carcinoma. Cancer 98: 1423-1429, 2003.

25. Khunnarong J, Tangjitgamol S, Manusirivithaya S, Suekwattana P and Leelahakorn S: Expression of cyclooxygenase-1 in epithelia ovarian cancer: a clinicopathological study. Asian Pac J Cancer Prev 9: 757-762, 2008

26. Urick ME, Giles JR and Johnson PA: VEGF expression and the effect of NSAIDs on ascites cell proliferation in the hen model of ovarian cancer. Gynecol Oncol 110: 418-424, 2008.

27. Li W, Wang J, Jiang HR, Xu XL, Zhang J, Liu ML and Zhai LY: Combined effects of cyclooxygenase- 1 and cyclooxygenase- 2 selective inhibitors on ovarian carcinoma in vivo. Int J Mol Sci 12: 668-681, 2011

28. Harlozinska A, Sedlaczek P, Kulpa J, Grybos M, Wójcik E, Van Dalen A and Einarsson R: Vascular endothelial growth factor (VEGF) concentration in sera and tumor effusions from patients with ovarian carcinoma. Anticancer Res 24: 1149-1157, 2004.

29. Prager GW and Poettler M: Angiogenesis in cancer. Basic mechanisms and therapeutic advances. Hamostaseologie 32: Aug 12, 2011 (Epub ahead of print)

30. Hicklin DJ and Ellis LM: Role of the vascular endothelial growth factor pathway in tumor growth and angiogenesis. J Clin Oncol 23: 1011-1027, 2005

31. Senger DR, Van de Water L, Brown LF, Nagy JA, Yeo KT, Yeo TK, Berse B, Jackman RW, Dvorak AM and Dvorak HF: Vascular permeability factor (VPF, VEGF) in tumor biology. Cancer Metastasis Rev 12: 303-324, 1993.
32. Li L, Wang L, Zhang W, Tang B, Zhang J, Song H, Yao D, Tang Y, Chen X, Yang Z, et al: Correlation of serum VEGF levels with clinical stage, therapy efficacy, tumor metastasis and patient survival in ovarian cancer. Anticancer Res 24: 1973-1979, 2004.

33. Yamamoto S, Konishi I, Mandai M, Kuroda H, Komatsu T, Nanbu K, Sakahara H and Mori T: Expression of vascular endothelial growth factor (VEGF) in epithelia ovarian neoplasms: correlation with clinicopathology and patient survival and analysis of serum VEGF levels. Br J Cancer 76: 1221-1227, 1997.

34. von Rahden BH, Stein HJ, Pühringer F, Koch I, Langer R, Piontek G, Siewert JR, Höfler H and Sarbia M: Coexpression of cyclooxygenases (COX-1, COX-2) and vascular endothelial growth factors (VEGF-A, VEGF-C) in esophageal adenocarcinoma. Cancer Res 65: 5038-5044, 2005.

35. Li W, Xu RJ, Lin ZY, Zhuo GC and Zhang HH: Effects of a cyclooxygenase-1-selective inhibitor in a mouse model of ovarian cancer, administered alone or in combination with ibuprofen, a nonselective cyclooxygenase inhibitor. Med Oncol 26: 170-177, 2009.

36. Li Y, Guo Z, Han YP and Guo XY: Expressions of MVD, VEGF, Ki67 in residual prostate cancer after cryoablation. Clin Oncol Cancer Res 8: 27-32, 2011.

37. Zhou YJ, Xiong YX, Wu XT, Shi D, Fan W, Zhou T, Li YC and Huang X: Inactivation of PTEN is associated with increased angiogenesis and VEGF overexpression in gastric cancer. World J Gastroenterol 10: 3225-3229, 2004.

38. Wang J, Lv F, Fei X, Cui Q, Wang L, Gao X, Yuan Z, Lin Q, Lv Y and Liu A: Study on the characteristics of contrast-enhanced ultrasound and its utility in assessing the microvessel density in ovarian tumors or tumor-like lesions. Int J Biol Sci 7: 600-606, 2011.

39. Goodheart MJ, Ritchie JM, Rose SL, Fruehauf JP, De Young BR and Buller RE: The relationship of molecular markers of p53 function and angiogenesis to prognosis of stage I epithelial ovarian cancer. Clin Cancer Res 11: 3733-3742, 2005.

40. Guşet G, Costi S, Lazăr E, Dema A, Cornianu M, Vernic C and Păiuşan L: Expression of vascular endothelial growth factor (VEGF) and assessment of microvascular density with CD34 as prognostic markers for endometrial carcinoma. Rom J Morphol Embryol 51: 677-682, 2010

41. Cantu De León D, Lopez-Graniel C, Frias Mendivil M, Chanona Vilchis G, Gomez C and De La Garza Salazar J: Significance of microvascular density (MVD) in cervical cancer recurrence. Int J Gynecol Cancer 13: 856-862, 2003.

42. Meresman G: Relevance of apoptosis in the female reproductive system. Invest Clin 52: 274-290, 2011.

43. Forones NM, Carvalho AP, Giannotti-Filho O, Lourenço LG and Oshima CT: Cell proliferation and apoptosis in gastric cancer and intestinal metaplasia. Arq Gastroenterol 42: 30-34, 2005.

44. Munkarah AR, Morris R, Baumann P, Deppe G, Malone J, Diamond MP and Saed GM: Effects of prostaglandin E(2) on proliferation and apoptosis of epithelial ovarian cancer cells. J Soc Gynecol Investig 9: 168-173, 2002.

45. Kumar S, Mahdi H, Bryant C, Shah JP, Garg G and Munkarah A: Clinical trials and progress with paclitaxel in ovarian cancer. Int J Womens Health 2: 411-427, 2010. 